\title{
Hubungan Rasio Neutrofil Limfosit dengan Hipertensi Arteri Pulmonal pada Anak dengan Penyakit Jantung Bawaan Asianotik
}

Galih Herlambang, Sri Lilijanti Widjaja, Yulidar Hafidh, Harsono Salimo

Bagian Ilmu Kesehatan Anak Fakultas Kedokteran Universitas Sebelas Maret/RSUD dr. Moewardi Surakarta

Latar belakang. Hipertensi arteri pulmonal (HAP) merupakan komplikasi yang sering terjadi penyakit jantung bawaan (PJB). Peningkatan tekanan vaskular paru disebabkan oleh disfungsi sel endotel paru yang ditandai oleh inflamasi perivaskular. Rasio neutrofil limfosit (RNL) merupakan salah satu penanda biologis inflamasi yang murah dan mudah dan berhubungan dengan penyakit jantung. Tujuan. Untuk mengetahui hubungan RNL dengan HAP pada anak dengan PJB asianotik.

Metode. Penelitian potong lintang pada pasien anak usia 1 bulan - 18 tahun dengan penyakit jantung bawaan sianotik yang dirawat dan/atau poliklinik anak RSUD dr. Moewardi Surakarta antara Januari 2018 - Januari 2019. Diagnosis HAP berdasarkan pemeriksaan ekokardiografi Doppler. Semua subyek dilakukan pemeriksaan darah rutin lengkap. Analisis data dengan uji t tidak berpasangan, uji Mann Whitney dan uji chi squarelfisher exact test.

Hasil. Tiga puluh pasien PJB asianotik (aliran sistemik ke paru) terdiri atas 17 anak laki-laki, 13 anak perempuan. Hipertensi arteri pulmonal terjadi pada 17 pasien dan tidakHAP sebanyak 13 pasien. Defek PJB paling banyak defek septum atrium (DSA) dan defek septum ventrikel (DSV). Rasio neutrofil limfosit pada HAP lebih tinggi daripada tidak HAP pada anak dengan PJB asianotik $(3,56 \pm 1,07$ vs 2,04 $\pm 0,34 ; \mathrm{p}<0,001)$. Nilai cut offpoint RNL sebesar 2,355 dengan nilai AUC sebesar 0,901 dengan sensitivitas $84,2 \%$ dan spesifisitas $84,6 \%$.

Kesimpulan. Peningkatan RNL berhubungan dengan HAP pada anak dengan PJB asianotik. Sari Pediatri 2019;21(2):96-101

Kata kunci: RNL, HAP, PJB asianotik

\section{The Association between Neutrophil Lymphocyte Ratio and Pulmonary Arterial Hypertension in Pediatrics with Acyanotic Congenital Heart Disease}

Galih Herlambang, Sri Lilijanti Widjaja, Yulidar Hafidh, Harsono Salimo

Background. Pulmonary arterial hypertension is a complication which often occurs in congenital heart disease. Increased pulmonary vascular resistance is caused by pulmonary endothelial cell dysfunction characterized by perivascular inflammation. Neutrophil lymphocyte ratio is one of the affordable and easy biomarkers of inflammation and it is associated with heart disease.

Objective. To determine the association between neutrophil lymphocyte ratio and pulmonary arterial hypertension in children with acyanotic congenital heart disease.

Methods. Cross sectional study was conducted in children aged 1 month - 18 years with acyanotic congenital heart disease in pediatric ward and/or outpatient clinic of Dr. Moewardi Hospital Surakarta between January 2018 -January 2019. The diagnosis of pulmonary arterial hypertension was based on Doppler echocardiography. All subjects underwent a complete blood count examinations. All data were analyzed with unpaired t-test, Mann Whitney test and chi-square/fisher exact test.

Results. Thirty patients with acyanotic congenital heart disease (systemic to pulmonary shunt) consisted of 17 male and 13 female children. Pulmonary arterial hypertension occurred in 17 patients. Most of heart defects were caused by atrial septal and ventricular septal defects. Neutrophil lymphocyte ratio in pulmonary arterial hypertension was higher than that of it non pulmonary arterial hypertension in children with acyanotic congenital heart disease $(3.56 \pm 1.07$ vs $2.04 \pm 0.34 ; \mathrm{p}<0.001)$. The cut off point of neutrophil lymphocyte ratio was 2.355 with an AUC value of 0.901 , sensitivity of $84.2 \%$ and specificity of $84.6 \%$.

Conclusion. Increased neutrophil lymphocyte ratio is significantly associated with pulmonary arterial hypertension in children with acyanotic congenital heart disease. Sari Pediatri 2019;21(2):96-101

Keywords: neutrophil lymphocyte ratio, pulmonary arterial hypertension, acyanotic congenital heart disease

Alamat korespondensi: Galih Herlambang. Bagian Ilmu Kesehatan Anak Fakultas Kedokteran Universitas Sebelas Maret/RSUD dr. Moewardi Surakarta. Email:galih_uns@yahoo.com 
Galih Herlambang dkk: Perbedaan status perkembangan dan pertumbuhan anak dengan PJB sianotik dan non-sianotik

$\mathrm{H}$ ipertensi arteri pulmonal (HAP) adalah penyakit yang disebabkan oleh adanya peningkatan aliran darah paru dan/ atau resistensi pembuluh darah paru. ${ }^{1,2}$ Prevalensi penyakit ini sebesar 2,1-4,4 per 1.000.000 populasi. ${ }^{3}$ Penyakit ini dapat menyebabkan komplikasi gagal jantung kanan dan memiliki angka mortalitas yang tinggi mencapai $25 \%$, terutama pada 1 tahun pertama pemantauan. ${ }^{4}$ Faktor risiko yang menyebabkan penyakit semakin berat antara lain: sinkop, aktivitas fungsional menurut World Health OrganizationFunctional Class (WHO-FC) III/IV, peningkatan kadar NT-proBNP, tingginya resistensi vaskular paru, dan tingginya tekanan atrium kanan. ${ }^{5}$

Biomarker yang diteliti dan digunakan pada pasien hipertensi arteri pulmonal semakin luas. ${ }^{6}$ Salah satunya adalah rasio neutrofil limfosit. ${ }^{6}$ Rasio neutrofil limfosit (RNL) merupakan perbandingan jumlah neutrofil terhadap limfosit. Kelebihan biomarker tersebut adalah sederhana dan murah. ${ }^{7}$ Beberapa penelitian menyatakan bahwa RNL dapat digunakan untuk menilai beratnya penyakit atau keluaran penyakit pada pasien dengan hipertensi arteri pulmonal. ${ }^{7,8}$ Penelitian tentang RNL sebagai diagnosis dilakukan oleh Yildiz $\mathrm{dkk}^{9}$ dengan hasil cut off point RNL 1,65 dengan sensitivitas 72\% dan spesifitas 69\%. ${ }^{9}$ Rasio neutrofil limfosit sebagai biomarker prognosis didapatkan hubungan antara RNL dengan hasil/prognosis yang buruk pada pasien hipertensi arteri pulmonal. ${ }^{7,8}$ Penelitian-penelitian di atas masih terbatas pada pasien dewasa dengan HAP. Hubungan RNL pada pasien anak dengan HAPbelum banyak diteliti. Selain itu, nilai normal atau cut off point dari RNL belum ada kesepakatan baik pada dewasa maupun anak-anak. Oleh karena itu, peneliti ingin mengetahui adanya hubungan RNL dengan HAP pada anak dengan PJB asianotik.

\section{Metode}

Penelitian potong lintang di ruang perawatan dan/ atau poliklinik anak RSUD dr. Moewardi antara bulan Januari 2018 - Januari 2019. Subjek penelitian adalah pasien anak usia 1 bulan -18 tahun dengan diagnosis PJB asianotik aliran sistemik ke paru. Pengambilan sampel secara konsekutif dengan kriteria inklusi adalah usia 1 bulan - 18 tahun dengan PJB asianotik aliran sistemik ke paru, seperti defek septum atrium, defek septum ventrikel, dan duktus arteriosus persisten.
Kriteria eksklusi adalah mengalami sepsis, kanker, trauma berat, operasi besar, dan sindrom Down.

Diagnosis HAP dengan pemeriksaan ekokardiografi oleh seorang kardiolog anak dengan estimasi tekanan sistolik arteri pulmonalis $>35 \mathrm{mmHg}$ sebagai HAP dengan estimasi tekanan regurgitasi trikuspid $>20 \mathrm{mmHg}$ (asumsi perbedaan regurgitasi trikuspid dengan tekanan atrium kanan sebesar $10 \mathrm{mmHg}$ ). ${ }^{1,10}$ Pemeriksaan darah rutin diukur dengan alat hemoanalyzer otomatis dan dilakukan perhitungan rasio neutrofil limfosit. Penelitian ini dilakukan atas persetujuan orang tua atau wali dengan cara menandatangani informed consent yang diajukan oleh peneliti. Analisis statistik hubungan rasio nuetrofil limfosit terhadap HAP dengan uji t tidak berpasangan dengan alternatif uji nonparamterik uji Mann Whitney dan uji chi squarelfisher exact test. Nilai cut off point RNL terhadap HAPdengan analisis kurva ROC. Hasil uji statistik dinilai signifikan bila nilai $\mathrm{p}<$ 0,05 . Penelitian ini telah mendapatkan persetujuan dari Komite Etik Penelitian Kesehatan RSUD dr. MoewardiFK UNS Surakarta.

\section{Hasil}

Penelitian ini dilakukan pada 30 pasien PJB asianotik berusia 1 bulan sampai dengan 18 tahun yang dirawat di ruang perawatan dan/atau poliklinik anak RSUD dr. Moewardi Surakarta antara Januari 2018 sampai dengan Januari 2019. Usia rata-rata pada penelitian ini adalah 76-77 bulan. Jumlah laki-laki lebih banyak daripada perempuan. Defek PJB asianotik yang paling banyak adalah defek septum atrium dan defek septum ventrikel. Karateristik dasar subjek penelitian sebagai berikut tertera pada Tabel 1 .

Pada Tabel 1 di atas menunjukkan bahwa pasien PJB asianotik dengan HAP dan bukan HAP tidak terdapat perbedaan yang karakteristik yang signifikan berdasarkan variabel usia, jenis kelamin, lama terapi, aktivitas fungsional, fraksi ejeksi, diameter defek, rasio E/A, rasio LA/Ao, kadar hemoglobin, red cell distribution width (RDW), trombosit, mean platelet volume (MPV), leukosit, neutrofil, dan diagnosis ( $p>0,005)$. Diagnosis pasien anak dengan PJB asianotik yang mengalami HAP mayoritas ASD ada $47,1 \%$ anak dan pasien yang tidak mengalami HAP matoritas juga dengan diagnosis ASD ada $46,2 \%$ anak. Nilai $p=0,514(p>0,05)$ menunjukkan bahwa tidak terdapat perbedaan yang signifikan karakteristik 
Galih Herlambang dkk: Hubungan RNL dengan HAP pada anak dengan PJB asianotik

Tabel 1. Karakteristik dasar subjek penelitian

\begin{tabular}{|c|c|c|}
\hline \multirow{2}{*}{ Variabel } & \multicolumn{2}{|c|}{ Hipertensi arteri pulmonal } \\
\hline & $\mathrm{Ya}(\mathrm{n}=17)$ & Tidak $(\mathrm{n}=13)$ \\
\hline Usia (bulan) & $77,47 \pm 59,80$ & $76,54 \pm 54,66$ \\
\hline \multicolumn{3}{|l|}{ Jenis kelamin (\%) } \\
\hline Laki-laki & $10(58,8)$ & $7(53,8)$ \\
\hline Perempuan & $7(41,2)$ & $6(46,2)$ \\
\hline Lama_terapi & $21,00 \pm 16,39$ & $16,69 \pm 17,55$ \\
\hline \multicolumn{3}{|c|}{ Aktifitas fungsional (\%) } \\
\hline Grade 1 & $7(41,2)$ & $9(69,2)$ \\
\hline Grade 2 & $6(35,3)$ & $4(30,8)$ \\
\hline Grade 3 & $4(23,5)$ & $0(0,0)$ \\
\hline $\mathrm{EF}(\%)$ & $72,59 \pm 9,61$ & $75,92 \pm 7,62$ \\
\hline Diameter_defek & $11,90 \pm 9,21$ & $11,92 \pm 8,02$ \\
\hline \multicolumn{3}{|l|}{$\mathrm{E} / \mathrm{A}(\%)$} \\
\hline$<1$ & $3(17,6)$ & $2(15,4)$ \\
\hline$>1$ & $14(82,4)$ & $11(84,6)$ \\
\hline LA/Ao & $1,87 \pm 2,68$ & $1,43 \pm 0,57$ \\
\hline $\mathrm{Hb}$ & $12,24 \pm 1,77$ & $12,13 \pm 1,76$ \\
\hline RDW & $15,32 \pm 3,26$ & $13,83 \pm 1,68$ \\
\hline Trombosit & $298058,82 \pm 108846,49$ & $325461,54 \pm 64357,87$ \\
\hline MPV & $8,60 \pm 2,17$ & $8,16 \pm 0,75$ \\
\hline Leukosit & $10276,47 \pm 4273,83$ & $9161,54 \pm 2397,41$ \\
\hline Neutrofil & $61,93 \pm 14,90$ & $57,71 \pm 13,20$ \\
\hline Limfosit & $18,47 \pm 6,03$ & $28,65 \pm 6,81$ \\
\hline \multicolumn{3}{|l|}{ Diagnosis (\%) } \\
\hline ASD & $8(47,1)$ & $6(46,2)$ \\
\hline VSD & $5(29,4)$ & $3(23,1)$ \\
\hline PDA & $3(17,6)$ & $1(7,7)$ \\
\hline AVSD & $1(5,9)$ & $3(23,1)$ \\
\hline
\end{tabular}

Keterangan:

ASD: atrial septal defect

VSD: ventricular septal defect

PDA: patent ductus arteriosus

AVSD: atrioventricular septal defect

pasien anak PJB asianotik dengan HAP dan tanpa HAP berdasarkan hasil diagnosis. Berdasarkan uraian di atas maka dapat diketahui bahwa karakteristik dasar subyek penelitian ini homogen $(p>0,05)$ antara pasien anak PJB asianotik dengan HAP dan tanpa HAP.

Hubungan RNL dengan HAP pada pasien anak PJB asianotik disajikan dengan uji independen t test dengan hasil pasien yang mengalami HAP rata-rata $3,56 \pm 1,07$ dan pasien yang tidak mengalami HAP ratarata $2,04 \pm 0,34(\mathrm{p}=<0,001)$ tertera pada Gambar 1 .

Berdasarkan kurva ROC didapatkan nilai AUC sebesar 0,901 dengan nilai $\mathrm{p}<0,001(\mathrm{p}<0,01)$. Nilai cut off value untuk RNL adalah 2,355 yaitu pada sensitivity $=84,2 \%$ dan 1-specificity $=84,6 \%($ Gambar 2$)$.

\section{Pembahasan}

Hipertensi arteri pulmonal merupakan komplikasi yang sering terjadi pada PJB khususnya pasien dengan aliran pirau dari kiri ke kanan (sistemik ke paru). Peningkatan aliran darah ke paru yang persisten menyebabkan peningkatan tekanan arteri pulmonal melalui remodelling dan disfungsi pembuluh darah. Hal 
Galih Herlambang dkk: Perbedaan status perkembangan dan pertumbuhan anak dengan PJB sianotik dan non-sianotik

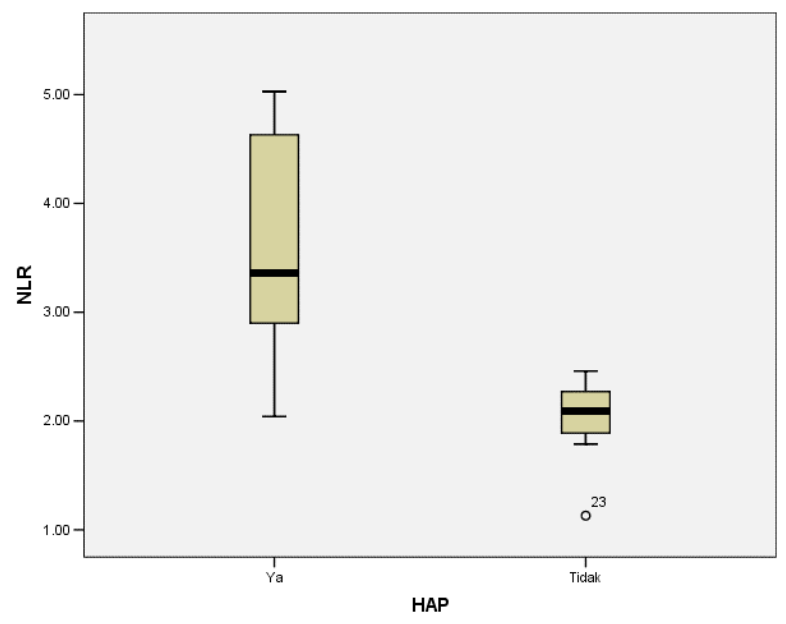

Gambar 1. Perbandingan RNL antara pasien dengan HAP dan tanpa HAP pada pasien anak PJB asianotik

tersebut meningkatkan tekanan resistensi vaskular paru dan peningkatan tekanan atrium kanan. ${ }^{11}$ Kejadian HAP pada penelitian ini sebesar $56,7 \%$ pada PJB asianotik. Hasil ini memiliki angka kejadian lebih besar dubandingkan dengan penelitian lainnya, seperti di Belanda yang melaporkan estimasi prevalensi HAP pada PJB sekitar 4-15\%. ${ }^{12}$ Di Eropa data register menunjukkan prevalensi secara keseluruhan HAP pada dewasa dengan PJB sekitar 4-28\% dan prevalensi sindrom Eisenmenger sebesar 1-6\%. ${ }^{12,13}$ Prevalensi HAP yang tinggi terjadi di studi UK National Pulmonary Hypertension Audit sebesar 30,2\% pada akibat PJB setelah penyebab idiopatik sebesar 33,6\% dan diikuti penyakit jaringan ikat yang berhubungan dengan HAP $(28,3 \%){ }^{14}$

Berdasarkan jenis defek PJB asianotik tanpa dilakukan operasi tutup defek, kejadian HAP pada penelitian ini disebabkan oleh defek ASD (47,1\%) diikuti VSD (29,4\%), PDA (17,6\%) dan AVSD $(5,9 \%)$. Hasil ini sesuai dengan penelitian Engelfriet $\mathrm{dkk}^{13}$ melaporkan HAP pada pasien yang lahir memiliki defek septum jantung terjadi pada 34\% dengan ASD tanpa operasi dan $28 \%$ VSD tanpa operasi, sedangkan $12 \%$ pada ASD dengan operasi tutup defek dan 13\% pada VSD dengan operasi tutup defek.

Penelitian tentang RNL pada HAP pada anak sangat terbatas. Pada penelitian ini didapatkan perbedaan bermakna pada RNL dan limfosit antara pasien PJB asianotik anak dengan dan tanpa HAP. Hasil ini sejalan dengan penelitian Yildiz A dkk $\mathrm{dkang}^{9}$

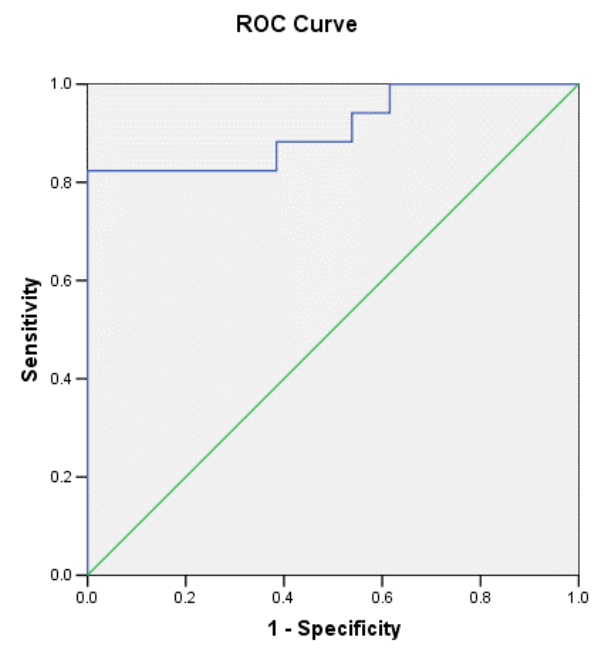

Gambar 2. Kurva ROC cut-off RNL berdasarkan hipertensi arteri pulmonal

melaporkan bahwa pada pasien dewasa dengan HAP terdapat perbedaan bermakna pada kadar limfosit dan RNL dibandingkan kelompok kontrol. Pada penelitian ini didapatkan nilai cutoff point RNL sebesar 2,355 dengan nilai sensitivitas $84,2 \%$ dan spesifitas $84,6 \%$. Hasil ini sedikit lebih tinggi dibandingkan hasil penelitian HAP pada pasien dewasa dengan nilai cutoff point 1,65 dengan sensitivitas $72 \%$ dan spesifitas 69\%. ${ }^{8}$ Dengan demikian, RNL dapat dijadikan sebagai prediktor adanya HAP dengan keunggulan murah, mudah, dan praktis untuk digunakan.

Peningkatan resistensi vaskular paru pada pasien dengan HAP disebabkan oleh adanya disfungsi endotel, proses remodelling vaskular, vasokontriksi, dan mikrotrombosis arteri pulmonalis., ${ }^{9} 15$ Peningkatan RNL pada HAP tidak terlepas dari proses inflamasi akibat disfungsi endotel dan proses remodelling vaskular arteri pulmonal. Subtipe leukosit memiliki peran penting dalam memodulasi respons inflamasi pada patogenesis HAP. Terutama, limfositopenia adalah temuan umum pada status inflamasi kritis dikarenakan peningkatan apoptosis limfosit 47 CD4+, FoxP3+, dan CD25+ adalah reseptor limfosit $\mathrm{T}$ regulator (Treg) yang bertanggung jawab untuk toleransi imunitas perifer dan berkurang pada penyakit autoimun, sedangkan CD8+ merupakan reseptor sel limfosit T sitotoksik. Pada HAP terdapat peningkatan sel regulator $\mathrm{CD} 4+$ dan penurunan sel $\mathrm{T}$ sitotoksik CD8+. Pada penelitian Ulrich $\mathrm{dkk}^{16}$ didapatkan hasil peningkatan bermakna kadar sel Treg CD4+, CD25+, 
FoxP3+ dan penurunan kadar sel Tc CD8+ di dalam darah pada pasien dengan HAP idiopatik.

Peningkatan Treg dalam darah kemungkinan dikaitkan dengan kebutuhan untuk menekan sel T reaktif itu sendiri (mungkin terhadap proliferasi endotel seperti kanker). ${ }^{9}$ Fungsi sel Treg secara alamiah adalah menekan aktivasi dan perluasan sel $T$ reaktif dan menghambat perkembangan penyakit autoimun serta membatasi cedera vaskular dan memainkan peran protektif terhadap perkembangan hipertensi arteri pulmonal. Kemungkinan penyebab lain adalah konversi sel T CD4+ menjadi sel Treg dapat diinduksi oleh infeksi mikroba, terutama virus. ${ }^{16}$ Hubungan beberapa infeksi virus kronis dengan hipertensi pulmonal telah diketahui dan beberapa temuan menunjukkan peran potensial mikroba (terutama virus) antigen mimikri dalam patogenesis HAP idiopatik. ${ }^{17,18}$ Meskipun demikian, sampai saat ini tidak ada antigen spesifik yang bisa dijelaskan secara konsisten.

Peningkatan neutrofil pada HAP dikaitkan dengan adanya peningkatan neutrofil elastase. Pada beberapa studi ditunjukkan adanya peningkatan neutrofil elastase pada sel otot polos dari pasien dengan hipertensi arteri pulmonal. ${ }^{19}$ Peningkatan neutrofil eleastase juga didapatkan pada sel otot polos paru dari tikus yang terpapar hipoksia kronis. ${ }^{20}$ Penekanan oleh neutrofil elastase menahan perkembangan dan menginduksi regresi hipertensi pulmonal yang diinduksi oleh eksprerimental sekunder terhadap injeksi monokrotalin. Pelepasan faktor pertumbuhan biologis aktif dari matriks ekstraseluler oleh elastase, elastin, dan fibronektin yang dihasilkan oleh aktivitas elastase bersifat sangat kemoatraktan untuk memberikan sinyal pada neutrofil. Elastase juga dapat mengaktifkan komponen sistem komplemen dimana memiliki kontribusi terhadap respons inflamasi imunitas tubuh. ${ }^{19}$

Penelitian ini memiliki beberapa kelemahan yaitu jumlah sampel yang sedikit sehingga kurang mewakili populasi yang ada dikarenakan penyakit ini jarang ditemukan. Penelitian ini juga tidak dapat menjelaskan informasi mengenai sebab atau akibatnya hubungan antara RNL dan HAP. Penggunaan sampel darah tunggal/selama satu kali pengukuran tidak akan mengantisipasi persistensi RNL dari waktu ke waktu.

\section{Kesimpulan}

Peningkatan RNL berhubungan dengan HAP pada anak dengan PJB asianotik.

\section{Daftar pustaka}

1. Park MK. Pulmonary hypertension. Dalam: Myung PK. Pediatric cardiology for practitioners. Edisi 5. United States of America. Mosby Elsevier; 2008.h.722-39.

2. Widlitz A, Barst RJ. Pulmonary hypertension in children. Eur Respir J. 2003; 21:156-76.

3. Jin H, Yang J, Zhang Q, Du J. Epidemiology and clinical management of pulmonary hypertension in children. Korean Circ I 2012;42:513-8.

4. Balkin EM, Olson ED, Robertson L, Adatia I, Fineman JR, dkk. Change in pediatric functional classifaction during treatment and mortabidity and mortality in children with pulmonary hypertension. Pediatr Cardiol 2016;37:756-64.

5. Żuk M, Mazurkiewicz-Antoń K, Migdał A, Kowalska DJ, Turska-Kmiec A, dkk. Prognosis in children with pulmonary arterial hypertension: 10-year single-centre experience. Kardiol Pol 2016;74:159-67.

6. Anwar A, Ruffenach G, Mahajan A, Eghbali M, Umar S. Novel biomarkers for pulmonary arterial hypertension. Respiratory Res 2016;17:1-10.

7. Özpelit E, Akdeniz B, Özpelit ME, Tas S, Bozkurt S, Tertemiz KC, Sevinç C, Badak Ö. Prognostic value of neutrophil-tolymphocyte ratio in pulmonary arterial hypertension. J Int Med Res 2015;43:661-71.

8. Harbaum L, Baaske KM, Simon M, Oqueka T, Sinning C, dkk. Exploratory analysis of the neutrophil to lymphocyte ratio in patients with pulmonary arterial hypertension. BMC Pulm Med 2017;17:1-9.

9. Yildiz A, Kaya H, Ertas F, Oylumlu M, Bilik MZ, dkk. Association between neutrophil to lymphocyte ratio and pulmonary arterial hypertension. Turk Soc Cardiol 2013;41:604-9.

10. Jone PN, Ivy DD. Echocardiography in pediatric pulmonary hypertension. Front Pediatr 2014;2:1-15.

11. D'Alto M dan Mahadevan VS. Pulmonary arterial hypertension associated with congenital heart disease. Eur Respir Rev 2012;21:328-37.

12. Duffels MG, Engelfriet PM, Berger RM, dkk. Pulmonary arterial hypertension in congenital heart disease: an epidemiologic perspective from a Dutch registry. Int J Cardiol 2007;120:198-204.

13. Engelfriet PM, Duffels MG, MöllerT, dkk. Pulmonary arterial hypertension in adults born with a heart septal defect: the Euro Heart Survey on adult congenital heart disease. Heart. 2007;93:682-7.

14. Dimopoulos K, Jon Wort S, Gatzoulis MA. Pulmonary hypertension related to congenital heart disease: a call for 
action. Eur Heart J 2014;35:691-700.

15. Huber LC, Bye H, Brock M. The pathogenesis of pulmonary hypertension: an update. Swiss Med Wkly 2015;145:14202.

16. Ulrich S, Nicolis MR, Taraseviciene L, Speich R, Voelkel N. Increased Regulatory and Decreased CD8+ Cytotoxic T Cells in the Blood of Patients with Idiopathic Pulmonary Arterial Hypertension. Respiration 2008;75:272-280.

17. Opravil M, Pechere M, Speich R, Joller-Jemelka HI, Jenni R, Russi EW, Hirschel B, Luthy R. HIV-associated primary pulmonary hypertension. A case control study. Swiss HIV Cohort Study. Am J Respir Crit Care Med 1997;155:990-5.
18. Marecki J, Cool C, Voelkel N, Luciw P, Flores S. Evidence for vascular remodeling in the lungs of macaques infected with simian immunodeficiency virus/HIV NEF recombinant virus. Chest 2005;128:621S-2S.

19. Rabinovitch M, Guignabert C, Humbert M, Nicolls MR.Inflammation and immunity in the pathogenesis of pulmonary arterial hypertension. Circ Res 2014;115:165-75.

20. Zaidi SHE, You XM, Ciura S, Husain M, Rabinovitch M. Overexpression of the serine elastase inhibitor elafin protects transgenic mice from hypoxic pulmonary hypertension. Circulation 2002;105:516-21. 